\title{
Proteinuria as the Most Relevant Parameter Affecting Fetuin-A Levels in Preeclampsia
}

\author{
Hussein Kadhem Al-Hakeim, Roaa Ali Muhammed Ali \\ Department of Chemistry, College of Science, University of Kufa, Iraq

\section{SUMMARY}

The present study aimed to examine the factors affecting the possible changes in serum fetuin-A in patients with preeclampsia (PE). The examined factors included the parameters of insulin resistance (IR) [(insulin sensitivity (HOMA\%S), insulin resistance (HOMA2IR), and beta-cell functions (HOMA\%B)], which were calculated using the HOMA2 calculator, and total and ionized calcium and magnesium levels.

Sixty PE patients and thirty healthy pregnant women, which comprised the study group and control group, respectively participated in the present study. Fetuin-A, estradiol, insulin, glucose, total and ionized calcium and magnesium, total protein, albumin, and globulins were measured in their sera.

The results of the present study showed that serum total and ionized magnesium and the I.Ca/Mg ratio decreased in PE women. Although the fasting insulin level and HOMA2IR were higher and HOMA2\%S was lower in PE compared with the control women, PE did not appear as an overt insulin-resistant state. Serum fetuin-A was low in PE patients compared with the control group because PE women had proteinuria. Fetuin-A levels were not correlated with the characteristics and IR parameters, cations, and estradiol levels, but it was correlated with the severity of proteinuria.

These results confirmed the hypothesis that proteinuria results in the loss of fetuin-A because it has a low molecular weight.

Key words: fetuin-A, insulin resistance, preeclampsia, magnesium, calcium

Corresponding author:

Hussein Kadhem Al-Hakeim

e-mail: headm2010@yahoo.com 


\section{INTRODUCTION}

Preeclampsia (PE) is generally defined as new hypertension and substantial proteinuria at or after the second half of gestation (1). It is a dangerous complication of pregnancy that affects $5-10 \%$ of pregnant women and leads to increased mortality of fetus and mothers (2). The exact mechanism of PE remains unknown. However, its pathogenesis is thought to occur in two phases, namely, the placental phase and maternal phase, which is characterized by an abnormal maternal endothelial response, resulting in hypertension, proteinuria, and edema (3).

Several risk factors have been identified with increased risk of $\mathrm{PE}$, including insulin resistance, diabetes mellitus, obesity, chronic hypertension, renal diseases, preexisting thrombophilia, smoking, and family history of PE (4). Fetuin-A is a carrier protein, such as albumin, that forms soluble complexes with calcium and phosphate; thus, fetuin-A is a carrier of the insoluble calcium phosphate (5).

Fetuin-A, a negative acute phase protein reactant (6), has been implicated in the pathophysiology of PE (7). Fetuin-A functions as an important component of diverse normal and pathological processes, including vascular calcification and bone metabolism regulation, insulin resistance, and protease activity control (8). Furthermore, fetuin-A is an inhibitor of the insulin receptor because of phosphorylation of tyrosine kinase activity, and its serum level is correlated with insulin resistance (9). Estradiol (E2) might affect the synthesis of fetuin-A, as suggested by the alteration in its levels after estrogen therapy and menopause (10).

Low serum calcium and/or magnesium may cause high blood pressure by stimulating parathyroid hormone and rennin release and also by inducing vasoconstriction by increasing its level in vascular smooth muscle (11). Calcium might also have an indirect effect on smooth muscle function by increasing magnesium levels (12).

The present study aims to examine the factors affecting the possible changes in serum fetuin-A in PE patients, as well as the factors that may affect fetuin-A levels, including insulin resistance state parameters [insulin resistance (HOMA2IR), insulin sensitivity $(\mathrm{HOMA} \% \mathrm{~S})$, and beta-cell functions (HOMA\%B)], which were calculated using the HOMA2 calculator, and total and ionized calcium and magnesium levels.

\section{SUBJECTS AND METHODS}

\section{Subjects}

A - Patients: Sixty PE female patients participated in the study. Their age range was $28.72 \pm 6.96$ years. The samples were collected from the "Labor Hall and Operation Hall" in Al-Zahra Teaching Hospital in Najaf Governorate-Iraq from August, 2014 to December, 2014. PE was diagnosed by a gynecologist, who treated patients during the pregnancy terms, using ICD-10 code O14 (International Classification of Diseases, $9^{\text {th }}$ and $10^{\text {th }}$ revisions). PE is defined as hypertension (systolic blood pressure $\geq 140 \mathrm{mmHg}$ and/or diastolic blood pressure $\geq 90 \mathrm{mmHg}$ measured twice after 20 weeks of gestation in combination with proteinuria $(\geq 1+$ dipstick proteinuria). Self-voiding was used for urine sampling. A single blood sample was taken from women with PE $(n=60)$ and control pregnant women who were matched for age $(+/-5$ years) and gestational age of 34 weeks ( $+/-12$ days). Blood samples were also obtained from 30 matched, healthy, pregnant women. The women were fasting. None was in active labor and none had ruptured membranes.

These studies were approved by the Kufa University Research Ethics Committee, and written consent was obtained from each participant.

B - Controls: Thirty apparently healthy women were selected as the control group. Their age range was $25.17 \pm 5.55$ years, which was comparable with that of patients with PE. None of these subjects suffered from hypertension.

C - Exclusion criteria: This study excluded patients with multifetal gestation, chronic hypertension, diabetes mellitus, autoimmune disease, renal disorder, maternal or fetal infection, and fetal congenital anomaly.

\section{Blood samples}

Maternal blood samples were obtained from an antecubital vein into plain tubes, allowed to clot for $15 \mathrm{~min}$, and centrifuged at $3000 \mathrm{~g}$ for $5 \mathrm{~min}$. The aliquots of serum were stored at $-18^{\circ} \mathrm{C}$ until further analyses. 


\section{Measurements}

Serum fetuin-A and E2 were measured using ELISA kits supplied by Monobind ${ }^{\circledR}$ (USA). Insulin levels in serum were measured using $\mathrm{DRG}^{\circledast}$ Insulin ELISA based on the sandwich principle.

Total calcium in serum was measured using a ready-to-use kit according to the Arsenazo III method. Corrected calcium was calculated using the following formula (13):

Corrected calcium $=$ total calcium $($ in $\mathrm{mg} / \mathrm{dl}) /$ $(0.6+0.05 \times$ total protein $)$

Ionized calcium levels in serum were calculated according to the following formula (13):

Ionized $\mathrm{Ca}=0.9+(0.55 \times \mathrm{T}$.Ca in $\mathrm{mmol} / \mathrm{l})-(0.3 \times$ albumin)

Total magnesium in serum was measured by the calamite method using a kit supplied by CypressCo. Serum ionized magnesium levels were calculated according to the following formula (14):

Ionized magnesium in $\mathrm{mmol} / \mathrm{L}=(0.66 \times(\mathrm{T} . \mathrm{Mg}$ in $\mathrm{mmol} / \mathrm{L}))+0.039$

Total protein, albumin, and glucose concentrations in serum were measured by colorimetric methods using ready-to-use kits supplied by Agapee ${ }^{\circledR}$ Company (Switzerland).

\section{Estimation of HOMA2IR, HOMA\%S, and HOMA\%B}

Insulin resistance parameters (HOMA2IR, $\mathrm{HOMA} \% \mathrm{~B}$, and $\mathrm{HOMA} \% \mathrm{~S}$ ) were calculated by a computer-based HOMA2 calculator (available at www.dtu.ox.ac.uk/homa) using fasting glucose and insulin. The model was recalibrated by the United Kingdom Prospective Diabetes Study (UKPDS) group at Oxford University to $100 \%$ in normal young adults when using currently available assays for measuring fasting blood glucose and insulin only. Ideal normalweight individuals aged $<35$ years should have HOMA2IR of $1 \mathrm{~mol} \cdot \mu \mathrm{U} / \mathrm{L}^{2}$ and $\mathrm{HOMA} \% \mathrm{~B}$ cell function of $100 \%$.

\section{Statistical analysis}

The distribution types of the results were examined using the Kolmogorov-Smirnov test. The results of the analysis divided the variables into two types according to the statistical distribution: the normally distributed variables and nonparametric variables.
For the normally distributed variables, the results were expressed as the mean \pm standard deviation. Pooled t-test was used to compare data between the patient and control groups and among subdivided groups in the measured parameters. Pearson's correlation coefficients ( $r$ ) were calculated to estimate the correlation between parameters.

For nonparametric variables that were not normally distributed, the results were expressed as medians, in addition to the mean \pm standard deviation. The Mann-Whitney $U$ test was used to compare data between the patient and control groups and among subdivided groups in the measured parameters. Spearman's correlation coefficients (Q, rho) were used to estimate the correlation between parameters.

The difference between groups was considered statistically significant when $p<0.05$. All statistical analyses were performed using SPSS Statistics version 19.0.1 Multilingual program (2010, IBM, USA). Figures were constructed using EXCEL (Microsoft Office 2010).

\section{RESULTS AND DISCUSSION}

\section{Comparison between PE and control groups}

\section{Descriptive parameters}

The results of descriptive variables in PE and control groups are presented in Table 1. The results showed significant differences $(p<0.05)$ in weight, height, BMI, and the percentages of having children and abortion between PE and normal pregnant women.

Table 1: Descriptive parameters in PE patients and control groups expressed as mean \pm standard deviation (N.S. $=$ not significant, $p$ value is not cited if $p>0.05$ )

\begin{tabular}{cccc}
\hline \hline Parameter & Patients & Control & p-value \\
\hline Age yr. & $28.72 \pm 6.96$ & $25.17 \pm 5.55$ & 0.011 \\
\hline Wt kg & $86.00 \pm 10.70$ & $74.67 \pm 7.75$ & $<0.001$ \\
\hline Height cm & $1.57 \pm 0.21$ & $1.56 \pm 0.14$ & 0.002 \\
\hline BMI kg/m² & $34.77 \pm 4.49$ & $30.65 \pm 3.33$ & $<0.001$ \\
\hline Wks of Preg. & $37.18 \pm 1.75$ & $37.63 \pm 0.67$ & N.S. \\
\hline Abortion & $\begin{array}{c}23 \% \\
(14 \text { out of } 60)\end{array}$ & $\begin{array}{c}10 \% \\
\text { out of } 30)\end{array}$ & 0.033 \\
\hline Having child & $\begin{array}{c}78.3 \% \\
(47 \text { out of } 60)\end{array}$ & $\begin{array}{c}70.0 \% \\
(21 \text { out of } 30)\end{array}$ & 0.037 \\
\hline \hline
\end{tabular}


These results indicated that BMI was significantly higher in the PE group than that in the control group, as noted previously (15). Previous studies found that overweight and obese women have elevated risks of PE, cesarean delivery, and childhood obesity compared with normal-weight women (16). The prevalence of PE varies considerably at both the country and facility levels. Furthermore, the history of chronic hypertension increases as BMI increases (17).

\section{Serum cation levels in patient and control groups}

The results showed significant decreases $(\mathrm{p}<0.05)$ in T.Mg $(0.79 \pm 0.23 \mathrm{mmol} / \mathrm{L}$ vs $.0 .89 \pm 0.17 \mathrm{mmol} / \mathrm{L})$, I.Mg $(0.56 \pm 0.15 \mathrm{mmol} / \mathrm{L}$ vs. $0.62 \pm 0.11 \mathrm{mmol} / \mathrm{L})$, and I.Ca/Mg (1.94 \pm 0.46 vs. $2.23 \pm 0.66)$ in PE patients compared with those in normal pregnant women. These results were in accordance with the results of Jafrinet al. (18) who found that the serum $\mathrm{Mg}^{2+}$ levels of women with mild and severe PE significantly decreased compared with those of the control group. Thus, the reduction in S.Mg2+ during pregnancy might be a possible contributor to the etiology of PE, and supplementation of this element to diet or drugs may be of value to prevent PE (18).

A number of reports have described the relationship between PE and $\mathrm{Ca}^{2+}$ and $\operatorname{Mg}^{2+}(19,20)$. Previous studies reported reduced levels of $\mathrm{Ca}^{2+}$ and $\mathrm{Mg}^{2+}$ in PE $(19,21)$. A possible theory to these findings may be that when S.Ca ${ }^{2+}$ levels decrease, the levels of intracellular Ca increase because of stimulating PTH release, leading to vasoconstriction of smooth muscles in blood vessels (22). However, in the present research, the decrease in $\mathrm{Ca}$ was statistically insignificant. Similarly, Richards et al. (23) found that woman with PE show no difference in Ca compared with normotensive women. This finding does not support the current belief that the mechanism by which $\mathrm{Ca}$ supplementation reduces the risk of developing PE is by correcting a nutritional deficiency.

In the present study, low levels of $\mathrm{Mg}$ in women with PE can be the result of decreased dietary intake, increased clearance by the kidneys, hemodilution caused by increased extracellular space, and increased consumption of minerals by the growing fetus (19). Recommendations by the WHO on the prevention and management of $\mathrm{PE}$ and eclampsia have consistently supported the belief that supplementation of minerals in pregnancy is associated with a significant reduction in the risk of PE (12).

\section{IR Parameters of patients and controls}

Table 2 presents the IR parameters in PE and control groups expressed as the mean \pm standard deviation and medians in brackets. Fasting insulin levels and HOMA2IR were higher $(p<0.05)$ in PE women than those in control women. By contrast, HOMA2\%S was lower $(p<0.05)$ in PE women than in control women.

Table 2: IR parameters in PE and control groups (data are expressed as the mean \pm standard deviation; median in brackets)

\begin{tabular}{cccc}
\hline \hline Parameter & Patients & Control & p-value \\
Insulin mIU/1 & $(7.77)$ & $(6.35)$ & 0.004 \\
FBS mmol/1 & $5.37 \pm 0.84$ & $5.19 \pm 0.36$ & N.S. \\
I/G IU/mol & $(1.49)$ & $(1.21)$ & N.S. \\
HOMA2\%B & $(82.45)$ & $(80.01)$ & N.S. \\
HOMA2\%S & $(92.40)$ & $(114.28)$ & 0.025 \\
HOMA2IR & $(2.10)$ & $(1.08)$ & 0.003 \\
\hline \hline
\end{tabular}

These results were confirmed by previous studies, in which people with high blood insulin levels have a higher risk for PE (24). Lampinen et al. (25) found that early PE may lead to IR disorder. Another study revealed a significant difference in IR state between PE and control groups during the third trimester (26). Practically, all obese women with hypertension have elevated insulin levels (27).

High risks for PE have been described under several situations associated with IR (28). Women with previous PE have an increased risk of developing type 2 diabetes mellitus (T2DM) later in life (3).

\section{S. fetuin-A in patients and controls}

Serum fetuin-A was significantly different $(\mathrm{p}<0.001)$ between patients $(741.60 \mu \mathrm{g} / \mathrm{ml})$ and controls $(1308.62 \mu \mathrm{g} / \mathrm{ml})$, as presented in Figure 1 . 


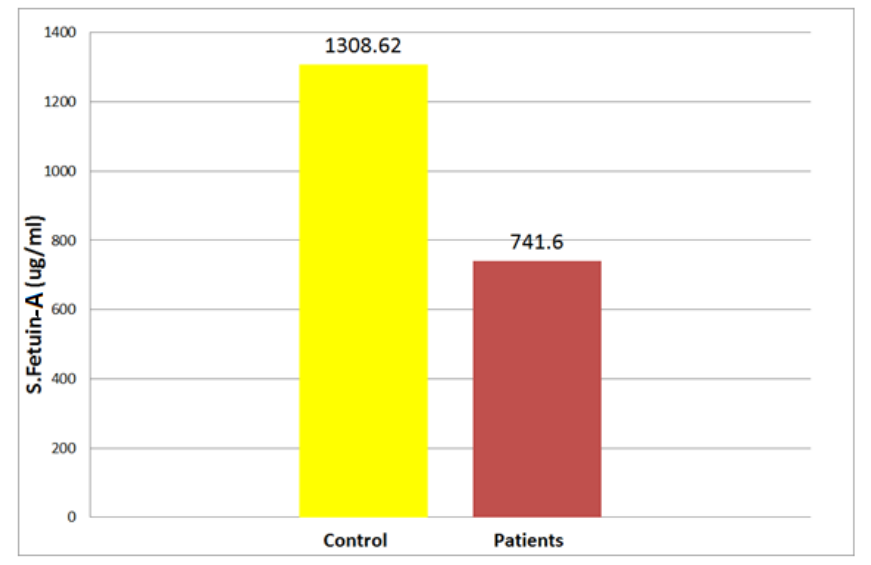

Figure 1: Serum fetuin-A in PE and control groups (data are expressed as median)

This decrease may be due to the fact that all PE women had proteinuria, and fetuin-A was excreted in urine with other small-molecular-weight proteins. Low fetuin-A was also reported in other studies (15, 29). Furthermore, fetuin-A has been implicated in the pathophysiology of PE $(7,8)$.

The rate of changes in maternal plasma concentrations of fetuin-A is positive (increases over time) in the midtrimester of normal pregnancy, but negative (decreases over time) in patients who subsequently develop PE (30).

\section{S.E2 in patients and control}

Serum E2 was statistically insignificant $(p=0.054)$ between patients $(97.52 \pm 27.63 \mathrm{pg} / \mathrm{ml})$ and controls $(106.79 \pm 17.09 \mathrm{pg} / \mathrm{ml})$.

These results were in agreement with findings reported by other researchers (31).

\section{Serum proteins in patients and controls}

Serum albumin and the Alb/Glb ratio in PE patients significantly decreased compared with those in the control group. By contrast, serum globulins in patients and control groups significantly increased.

The difference in serum total proteins between both groups was insignificant.

Table 3. Serum proteins in PE and control groups

\begin{tabular}{cccc}
\hline \hline Parameter & Control & Patients & p-value \\
Albumin g/dl & $4.19 \pm 0.41$ & $3.62 \pm 0.34$ & $0.017^{*}$ \\
T.Protein g/dl & $7.60 \pm 0.83$ & $7.37 \pm 1.15$ & 0.083 \\
S.Ig g/dl & $3.41 \pm 0.99$ & $3.75 \pm 0.45$ & $0.022^{*}$ \\
Alb/Glb & $1.23 \pm 0.30$ & $0.97 \pm 0.21$ & $0.041^{*}$ \\
\hline \hline
\end{tabular}

(*): Correlation is significant at the 0.05 level.
This result may be due to albumin loss in the heavy proteinuria state in PE patients. Another factor affecting S.albumin level is that hypoalbuminemia in $\mathrm{PE}$ is the result of reduced hepatic blood flow, which is secondary to hypovolemia created by higher filtration pressure in the capillaries (32).

Some studies reported that serum total protein is not significantly different between PE and control groups (33). However, other studies reported a significant decrease in serum total protein and albumin in PE women compared with that in the controls (34).

\section{Correlation between fetuin-A and the measured parameters}

\section{Fetuin-A vs. characteristics of the patients}

No relationship was found between clinical features (maternal age, BMI, and gestational age at blood draw) and serum fetuin-A levels in PE as noticed previously (15).

High levels of fetuin-A have been reported in women with syndromes associated with the IR such as T2DM (35), polycystic ovary syndrome (36), and obesity (37).

Research has shown that fetuin-A is correlated only with BMI, but neither showed a significant association with IR or serum insulin (38). The difference in the serum fetuin-A levels between PE patients and normotensive women remained significant after adjustment for maternal age, BMI, and gestational age at blood $\operatorname{draw}(15)$.

\section{Fetuin-A vs. IR parameters}

Serum fetuin-A is correlated with BMI, but neither shows a significant association with insulin sensitivity nor serum insulin. Kalabay et al. (38) showed that serum levels of fetuin-A was correlated with indirect parameters of maternal IR. Fetuin-A may contribute to IR during normal pregnancy and gestational diabetes (38). Fetuin-A is an inhibitor of the insulin receptor, and its serum levels are correlated with IR (10).

Fetuin-A inhibits the insulin receptor tyrosine kinase, preventing insulin-mediated autophosphorylation of the insulin receptor and inducing IR in muscle and fat $(39,40)$. A direct relationship was found between plasma fetuin-A and HOMA-IR. These findings were consistent with a possible pathogenic role of fetuin-A 
in exacerbating the IR and proatherogenic environment associated with T2DM (40).

Serum fetuin-A levels shows a significant positive correlation with HOMA-IR. The mean levels of HOMA-IR significantly and progressively increased across fetuin-A, and showed positive correlations with serum fasting c-peptide. Thus, the levels of serum fetuin-A are significantly associated with IR and arterial stiffness, whereas no associations with each microangiopathy in patients with T2DM have been reported (41). This study found a lack of significant associations of fetuin-A with IR in T2DM.

At a certain weight gain stage, fetuin- $A$ is significant for the development of IR. In terms of further progressive resistance with increasing weight in the obesity range, the present data did not support the role of fetuin-A. Similarly, its contribution to T2DM resistance is of minor importance (42).

Fetuin-A inhibits insulin receptor tyrosine kinase activity in the muscle and liver, thereby inhibiting insulin signaling and introducing IR in vitro (39).

Table 4: Correlation between divalent cations and other parameters

\begin{tabular}{|c|c|c|c|c|c|c|c|c|c|c|c|c|}
\hline & & & T.Mg & I.Mg & T.Ca & I..Ca & T.Ca/Mg & I. $\mathrm{Ca} / \mathrm{Mg}$ & Alb & T.Pr & S.Glb & $\mathrm{Alb} / \mathrm{Glb}$ \\
\hline \multirow{4}{*}{ Fetuin-A } & \multirow{2}{*}{ Patients } & r-value & 0.04 & 0.04 & 0.01 & 0.01 & -0.04 & -0.05 & $-0.27^{*}$ & -0.23 & -0.16 & 0.01 \\
\hline & & p-value & 0.79 & 0.79 & 0.94 & 0.99 & 0.77 & 0.74 & 0.03 & 0.08 & 0.21 & 0.95 \\
\hline & \multirow{2}{*}{ Control } & r-value & -0.16 & -0.16 & 0.16 & 0.16 & 0.18 & 0.19 & 0.02 & 0.21 & 0.22 & -0.19 \\
\hline & & p-value & 0.35 & 0.39 & 0.40 & 0.40 & 0.33 & 0.30 & 0.92 & 0.26 & 0.24 & 0.31 \\
\hline
\end{tabular}

Fetuin-A is a prominent serum glycoprotein and a major non-collagenous component of mineralized bone in mammals. Fetuin-A can inhibit or stimulate osteogenesi sin vitro, depending on its concentrations (47).

One of the functions of fetuin-A is to act as an inhibitor of calcification by increasing the blood solubility of $\mathrm{Ca}$ and phosphorus, and preventing spontaneous mineral precipitation in the vasculature (48).

\section{Fetuin-A vs. E2}

The results revealed no correlation between serum fetuin-A and serum E2 in the control $(r=0.122$, $\mathrm{p}>0.05)$ and PE groups $(\mathrm{r}=0.045, \mathrm{p}>0.05)$ (Figures 2 and 3 , respectively).
In humans, fetuin-A may be an important link between obesity and IR (37). Fetuin-A concentrations are also associated with hepatosteatosis, and they are elevated in patients with IR (43).

Recent studies have associated high levels of (44), IR, hepatosteatosis (43), and metabolic syndrome (37).

Fasting glucose levels were significantly positively correlated with fetuin-A levels. A previous study showed that high fetuin-A concentrations are associated with T2DM and IR (45). Another study reported that fetuin-A levels are significantly correlated with fasting plasma glucose and CRP (46).

\section{Fetuin-A vs. cations}

There is no correlation between the examined cations and ratios with serum fetuin-A in the PE patients and control group as presented in Table 4 . fetuin-A with an increased risk of T2DM incidence

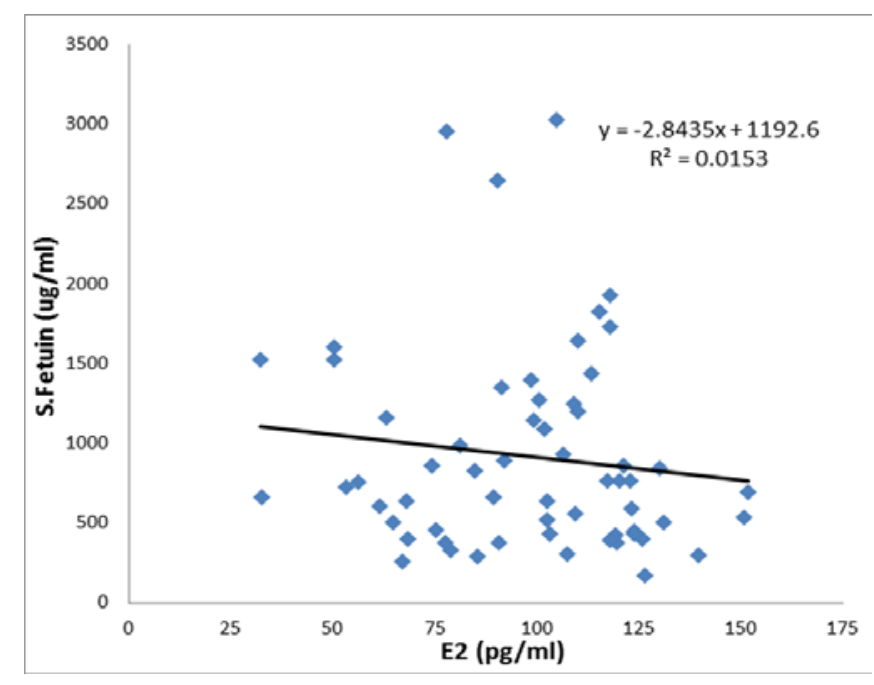

Figure 2: Correlation between serum fetuin-A and E2 in PE women 


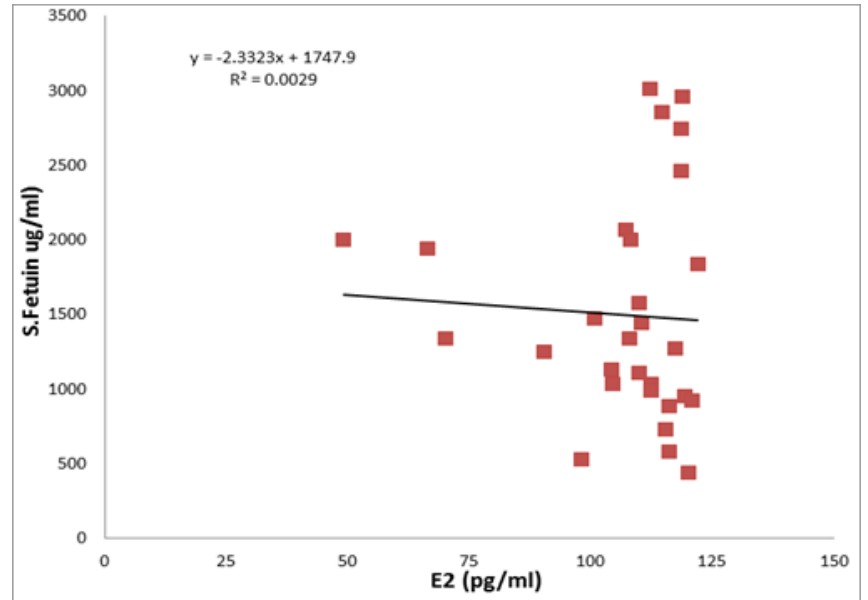

Figure 3: Correlation between serum fetuin-A and $E 2$ in control group

Serum fetuin-A levels were lower in patients with postmenopausal osteoporosis compared with that in the control group (49). Fetuin-A levels peaked in women using oral estrogens and reached middle levels for women not using oral estrogens. Low fetuin-A levels were found to be associated with age, but with lower levels of other cardiovascular disease risk factors, including adiposity, blood pressure, lipids, triglycerides, and IR (40).

\section{Correlation between fetuin-A and protein in urine}

The patients were divided into three groups according to the number of protein plus signs $(+)$ in urine using a dipstick strip. Significant differences in the serum fetuin-A levels were found among these groups (Table 5).
Table 5: S.fetuin-A in PE patients according to the level of proteinuria

\begin{tabular}{ccccc}
\hline $\begin{array}{c}\text { Protein in } \\
\text { Urine }(+)\end{array}$ & $\begin{array}{c}\text { No. of } \\
\text { Patients }\end{array}$ & $\begin{array}{c}\text { Percent } \\
\%\end{array}$ & $\begin{array}{c}\text { S. Fetuin A } \\
\text { Range } \\
(\text { Median })\end{array}$ & Comparison \\
\hline 1 & 14 & 23.3 & $\begin{array}{c}168.6-1929.5 \\
(618.6)\end{array}$ & $\begin{array}{c}1 \text { vs. } 2 \\
(\mathrm{p}<0.05)\end{array}$ \\
\hline 2 & 39 & 65.0 & $\begin{array}{c}286.8-3022.7 \\
(764.6)\end{array}$ & $\begin{array}{c}2 \text { vs. } 3 \\
(\mathrm{p} .<0.05)\end{array}$ \\
\hline 3 & 7 & 11.7 & $\begin{array}{c}689.0-2945.5 \\
(857.0)\end{array}$ & $\begin{array}{c}1 \text { vs. 3 } \\
(\mathrm{p}<0.01)\end{array}$ \\
\hline \hline
\end{tabular}

The results indicated a direct correlation between the protein lost in urine and S.fetuin-A level (Figure 4). The molecular weight of fetuin-A ranges from $51,000 \mathrm{Da}$ to $67,000 \mathrm{Da}$ depending on the carbohydrate content (50), which is close to the molecular weight of serum albumin. Therefore, both proteins were lost together through urine in PE patients with proteinuria.

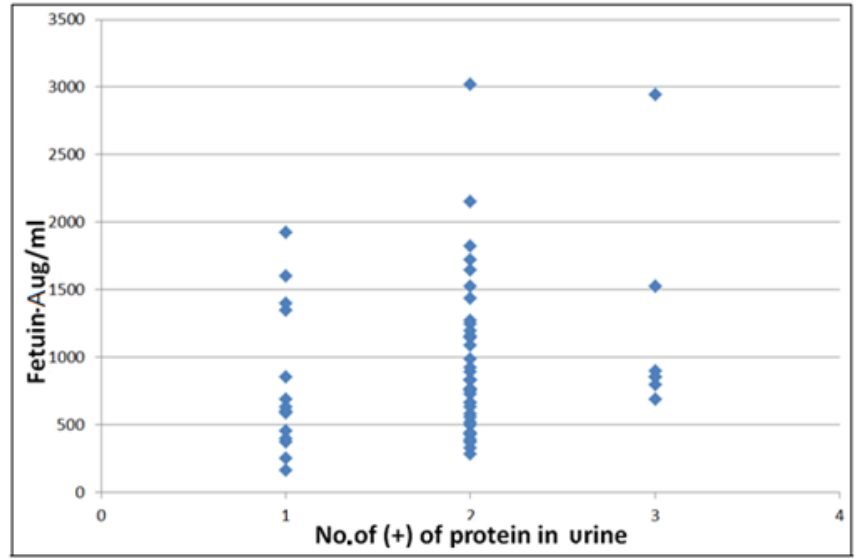

Figure 4: Correlation between S.Fetuin-A and proteinuria level in PE women

\section{CONCLUSION}

The present study showed that serum fetuin-A was directly proportional to proteinuria and inversely proportional to serum albumin in PE patients. These factors were the major factors affecting serum fetuinA levels in PE. 


\section{References}

1. Tersigni C, Frances chi F, Todros T et al. Insights into the Role of Helicobacter pylori Infection in Preeclampsia: From the Bench to the Bedside. Front Immunol 2014;5: 484.

http://dx.doi.org/10.3389/fimmu.2014.00484

2. North RA, McCowan LM. Dekker et al. Clinical risk prediction for pre-eclampsia in nulliparous women: development of model in international prospective cohort. BMJ 2011; 342:d1875. doi:10.1136/bmj.d1875.

http://dx.doi.org/10.1136/bmj.d1875

3. Carty DM. Pre-eclampsia; early prediction and long term Consequences. A PhD dissertation.Institute of Cardiovascular and Medical Sciences, School of Medicine, University of Glasgow, UK, 2002.

4. Sibai B, Dekker G, Kupferminc M. Pre-eclampsia. Lancet 2005; 365:785-99. http://dx.doi.org/10.1016/S0140-6736(05)71003-5

5. Heiss A, Eckert T, Aretz A, Richtering W, van Dorp W, Schäfer C, Jahnen-Dechent W. Hierarchical role of fetuin-A and acidic serum proteins in the formation and stabilization of calciumphosphate particles. J Biol Chem 2008;283:14815-25. doi:10.1074/jbc.M709938200. http://dx.doi.org/10.1074/jbc.M709938200

6. Wang H, Sama AE. Anti-inflammatory role of fetuin-A in injury and infection. Curr Mol Med 2012; 12:625-33.

http://dx.doi.org/10.2174/156652412800620039

7. Gomez LM. Understanding the effects of fetuin-A in pregnancy. Med J Obstet Gynecol 2013; 1:1010.

8. Mori K, Emoto $M$, Inaba M. Fetuin-A: a multifunctional protein. Recent Pat EndocrMetab Immune Drug Discov 2011; 5:124-46. http://dx.doi.org/10.2174/187221411799015372

9. Hashimoto S, Miwa M, Akasofu K, Nishida E. Changes in 40 serum proteins of post-menopausal women. Maturitas 1991; 13: 23-33.

10. Vörös K, Cseh K, Kalabay L. The role of fetuin-A in cardiovascular diseases. Orv Hetil. 2014; 155:1623.
http://dx.doi.org/10.1556/OH.2014.29793

11. Jain S, Sharma P, Kulshreshtha S, Mohan G, Singh $\mathrm{S}$. The Role of Calcium, Magnesium and Zinc in Pre-eclampsia. Biol Trace Elem Res 2010; 133:16270.

http://dx.doi.org/10.1007/s12011-009-8423-9

12. Hofmeyr GJ, Duley L, Atallah A. Dietary calcium supplementation for prevention of pre-eclampsia and related problems: a systematic review and commentary. BJOG 2007; 114:933-43. http://dx.doi.org/10.1111/j.1471-0528.2007.01389.x

13. Dickerson RN, Alexander KH, Minard G et al. Accuracy of methods to estimate ionized and "corrected" serum calcium concentrations in critically ill multiple trauma patients receiving specialized nutrition support. J Parenter Enteral Nutr 2004;28:133-41.

http://dx.doi.org/10.1177/0148607104028003133

14. Koch SM, Warters D, Mehlhorn U. The simulaneous measurement of ionized and total calcium and ionized and total magnesium in intensive care unit patients. J Criti Care 2002, 17: 203-5.

http://dx.doi.org/10.1053/jcrc.2002.35813

15. Molvarec A, Kalabay L, Derzsy $Z$ et al. Preeclampsia is associated with decreased serum a2-HS glycoprotein (fetuin-A) concentration. Hypertension Res 2009; 32, 665-9. http://dx.doi.org/10.1038/hr.2009.79

16. Bodnar LM, Siega-Riz AM, Simhan HN et al. Severe obesity, gestational weight gain, and adverse birth outcomes. Am J Clin Nutr 2010; 91: $1642-8$.

http://dx.doi.org/10.3945/ajcn.2009.29008

17. Bilano VL, OtaE, Ganchimeg $\mathrm{T}$ et al. Risk factors of pre-eclampsia/eclampsia and its adverse outcomes in low- and middle-income countries: A WHO secondary analysis. PLoS One 2014; 9: e91198.

http://dx.doi.org/10.1371/journal.pone.0091198

18. Jafrin W, Mia AR, Chakraborty PK et al. An evaluation of serum magnesium status in pre- 
eclampsia compared to the normal pregnancy. Mymensingh Med J 2014; 23:649-53.

19. Sandip S, Asha K, Paulin G, Hiren S, Gagandeip S, Amit V. A comparative study of serum uric acid, calcium and magnesium in preeclampsia and normal pregnancy. J Advanc Res Biol Sci 2013; 5:55-8.

20. Abdellah A, Abdrabo AA: Assessment of serum calcium, magnesium, copper and zinc levels in Sudanese pregnant women with preeclampsia. Glo Adv Res J Med Sci 2014; 3:33-6.

21. Ephraim RKD, Osakunor DNM, Denkyira SW et al. Serum calcium and magnesium levels in women presenting with preeclampsia and pregnancy-induced hypertension: a case-control study in the Cape Coast metropolis, Ghana. BMC Pregnancy Childbirth 2014; 14: 390.

http://dx.doi.org/10.1186/s12884-014-0390-2

22. Selina A, Shelina B, Sultana F. Calcium and Zinc deficiency in preeclamptic women. J Bangladesh Soc Physiol 2011; 6:94-9.

23. Richards DG, Lindow SW, Carrara $\mathrm{H}$ et al. A comparison of maternal calcium and magnesium levels in preeclamptic and normotensive pregnancies: an observational case-control study. BJOG 2014; 121:327-36.

http://dx.doi.org/10.1111/1471-0528.12436

24. Romero J, Spinedi E. Two-hour insulinemia after oral glucose overload and women at risk of pregnancy-induced hypertensive disorders. Hyperten in Pregnancy 2013; 32:355-66. http://dx.doi.org/10.3109/10641955.2013.807821

25. Lampinen $\mathrm{KH}$, Rönnback M, Groop P-H, Kaaja RJ. A relationship between insulin sensitivity and vasodilation in women with a history of preeclamptic pregnancy. Hypertension 2008; 52:394-401.

http://dx.doi.org/10.1161/HYPERTENSIONAHA.1 08.113423

26. AbhariFR, Andarieh MG, Farokhfar A, Ahmady S. Estimating Rate of Insulin Resistance in Patients with Preeclampsia Using HOMA-IR Index and Comparison with Nonpreeclampsia Pregnant Women. Biomed Res Int 2014; 2014: 140851.
27. Cunningham FG, Leveno KJ, Bloom SL et al. Manual of Obstetrics (Eds.) Williams. McGraw Hill, NY. 23rd ed.; 2010: 946-57.

28. Sinha S, Singh GP, Gupta K et al. Effect of preeclampsia on insulin sensitivity. Int J Appl Basic Med Res 2014;4: 7-10. doi: 10.4103/2229516X.125670. http://dx.doi.org/10.4103/2229-516X.125670

29. Chaemsaithong $\mathrm{P}$, Romero R, Tarca AL et al. Maternal plasma fetuin-A concentration is lower in patients who subsequently developed preterm preeclampsia than in uncomplicated pregnancy: a longitudinal study. J Matern Fetal Neonatal Med 2014; 29:1-10.

30. DiRenzo GC. The great obstetrical syndromes. J Matern Fetal Neonatal Med 2009;22:633-5. http://dx.doi.org/10.1080/14767050902866804

31. Valadan M, Qadrdoost N. and Davari-Tanha F. Androgen levels in preeclampsia. Acta Med Iranica 2006; 44:241-5.

32. Gojnic M, Petkovic S, Papic M et al. Plasma albumin level as an indicator of severity of preeclampsia. Clin Exp Obstet Gynecol 2004; 31:209-10.

33. Alavi A, Jahanshahi KA, Karimia $\mathrm{S}$ et al. Comparison of serum calcium, total protein and uric acid levels between hypertensive and healthy pregnant women in an Iranian population. Life Sci J 2012; 9:485-8.

34. Olooto WE, Mosuro AO, Adeleye AA, TA. Assessment of Total Protein, Albumin, Creatinine and Aspartate Transaminase level in Toxemia of pregnancy. Med Sci 2013; 13:791-6. http://dx.doi.org/10.3923/jms.2013.791.796

35. Ley $\mathrm{SH}$, Sun $\mathrm{Q}$, Jimenez $\mathrm{MC}$ et al. Association between alcohol consumption and plasma fetuin$\mathrm{A}$ and its contribution to incident type 2 diabetes in women. Diabetologia 2014; 57:93-101. doi:10.1007/s00125-013-3077-8. http://dx.doi.org/10.1007/s00125-013-3077-8

36. EnliY, FenkciSM, FenkciV,Oztekin O. Serum Fetuin-A levels, insulin resistance and oxidative stress in women with polycystic ovary syndrome. Gynecol Endocrinol 2013; 29:1036-9. http://dx.doi.org/10.3109/09513590.2013.829442 
37. Ix JH, Shlipak MG, Brandenburg VM et al. Association between human Fetuin-Aand the metabolic syndrome: data from the Heart and Soul Study. Circulation 2006; 113:1760-7. http://dx.doi.org/10.1161/CIRCULATIONAHA.10 5.588723

38. Kalabay L, Jakab L, Prohaszka Z, et al. Human fetuin/alpha2HS-glycoprotein level as a novel indicator of liver cell function and short-term mortality in patients with liver cirrhosis and liver cancer. Eur J Gastroenterol Hepatol 2002; 14: 389_ 94.

http://dx.doi.org/10.1097/00042737-20020400000009

39. Auberger $\mathrm{P}$, Falquerho L, Contreres JO, et al. Characterization of a natural inhibitor of the insulin receptor tyrosine kinase: cDNA cloning, purification, and anti-mitogenic activity. Cell 1989; 58: 631-40. http://dx.doi.org/10.1016/0092-8674(89)90098-6

40. LaughlinGA, CumminsK, WasselCL, et al. The association of fetuin-A with cardiovascular disease mortality in older community-dwelling adults: the Rancho Bernando study. J Am CollCardiol 2012; 59:1688-96.

http://dx.doi.org/10.1016/j.jacc.2012.01.038

41. Jung CH, Kim BY, Kim CH, Kang SK, Jung SH, Mok JO.. Associations of serum Fetuin-A levels with insulin resistance and vascular complications in patients with type 2 diabetes. DiabVasc Dis Res 2013; 10:459-67.

http://dx.doi.org/10.1177/1479164113490766

42. ErdmannJ, SalmhoferH, Knau A, et al. Relationship of Fetuin-A levels to weightdependent insulin resistance and type 2 diabetes mellitus.Regul Pept 2012; 178:6-10.

http://dx.doi.org/10.1016/j.regpep.2012.02.004

43. Stefan N, Hennige AM, Staiger H, et al. Alpha2Heremans-Schmid glycoprotein/Fetuin-A is associated with insulin resistance and fat accumulation in the liver in humans. Diabetes Care 2006; 29:853-7.

http://dx.doi.org/10.2337/diacare.29.04.06.dc051938

44. Ix JH, Biggs ML, Mukamal KJ, et al. Association of Fetuin-A with incident diabetes mellitus in community-living older adults: the cardiovascular health study. Circulation 2012; 125:2316-22.

http://dx.doi.org/10.1161/CIRCULATIONAHA.11 1.072751

45. Song $\mathrm{A}, \mathrm{Xu} \mathrm{M}, \mathrm{Bi} \mathrm{Y}$, et al. Serum Fetuin-A associates with type 2 diabetes and insulin resistance in Chinese adults. PLoS One 2011; 6:e19228.

http://dx.doi.org/10.1371/journal.pone.0019228

46. Ou HY, Yang YC, Wu HT, et al. Serum fetuin-A concentrations are elevated in subjects with impaired glucose tolerance and newly diagnosed type 2 diabetes.ClinEndocrinol (Oxf) 2011; 75:450-5. http://dx.doi.org/10.1111/j.1365-2265.2011.04070.x

47. Pamuk BO, Yilmaz H, Topcuoglu T, et al. FetuinA levels in hyperthyroidism. Clinics (Sao Paulo) 2013; 68:379-83.

http://dx.doi.org/10.6061/clinics/2013(03)OA15

48. Jahnen-Dechent W, Heiss A, Schäfer C, Ketteler M. Fetuin-Aregulation of calcified matrix metabolism. Circ Res 2011; 108:1494-509. http://dx.doi.org/10.1161/CIRCRESAHA.110.2342 60

49. Sari A, Uslu T. The Relationship Between FetuinAand Bone Mineral Density in Postmenopausal Osteoporosis. Turk J Rheumatol 2013; 28:195-201. http://dx.doi.org/10.5606/tjr.2013.2468

50. Brown WM1, Dziegielewska KM, Saunders NR, et al. The nucleotide and deduced amino acid structures of sheep and pig fetuin. Common structural features of the mammalian fetuin family. Eur J Biochem 1992; 205:321-31. http://dx.doi.org/10.1111/j.1432-1033.1992.tb16783.x 


\title{
Proteinurija kao najvažniji faktor koji utiče na nivoe fetuina kod preeklampsije
}

\author{
Hussein Kadhem Al-Hakeim, Roaa Ali Muhammed Ali \\ Departman za hemiju, Fakultet za nauku, Univerzitet u Kufi, Irak
}

\section{SAŽETAK}

Cilj ove studije bio je da ispita faktore koji utiču na moguće promene vrednosti fetuin-A u serumu kod trudnice sa preeklampsijom (PE). Ispitivani faktori su uključili parametre insulinske rezistencije (IR) [insulinska rezistencija (HOMA2IR), insulinska senzitivnost (HOMA\%S) i funkcija beta ćelija (HOMA\%B)], koji su izračunati pomoću HOMA2 kalkulatora, nivoa magnezijuma, ukupnog i jonizujućeg kacijuma.

U studiji je učestvovalo 60 trudnica sa PE koje su činile studijsku grupu i 30 zdravih trudnica koje su pripadale kontrolnoj grupi. U njihovom serumu određene su vrednosti: fetuin-A, estradiola, insulina, glukoze, magnezijuma i ukupnog i jonizujućeg kalcijuma i globulina.

Rezultati ove studije su pokazali da su ukupni i jonizujući nivoi magnezijuma u serumu kao i odnos I.Ca/Mg bili sniženi kod ispitanica sa PE. Premda su nivoi insulina nakon gladovanja i HOMA2IR bili povišeni, a nivoi HOMA\%S sniženi kod ispitanica sa $\mathrm{PE}$ u poređenju sa kontrolnom grupom, preeklampsija se nije manifestovala kao očigledno stanje insulinske rezistencije. Nivoi fetuin-A nisu bili u korelaciji sa karakteristikama i parametrima IR, katjonima, nivoima estradiola, ali su bili u korelaciji sa stepenom proteinurije.

Rezultati studije su potvrdili hipotezu da proteinurija dovodi do gubitka fetuin-A zbog njegove male molekularne težine.

Ključne reči: fetuin-A, insulinska rezistencija, preeklamsija, magnezijum, kalcijum 